\title{
CURRENT AND EMERGING CHALLENGES IN VOCATIONAL EDUCATION
}

\author{
DEEPAK CHAKRAVARTY ${ }^{1} \&$ DR. MAHIMA GUPTA ${ }^{2}$ \\ ${ }^{I}$ Research Scholar, Amity Institute of Education, Amity University Uttar Pradesh, India \\ ${ }^{2}$ Associate Professor, Amity Institute of Education, Amity University Uttar Pradesh, India
}

\begin{abstract}
This article will be dealing at the challenges facing the vocational education stream In India and suggestions to improve the quality of education imparted in the vocational streams. The NPE 2016 Committee recognizes the need for integrating skills with education, particularly in secondary education and outlines the challenges and broad strategy for the future. A comprehensive National Policy for Skill Development and Entrepreneurship was formulated in 2015 and a Mission was set up by Government of India, with the objective of training 40 crore people by 2022. In 83 order to implement the Mission, necessary institutional frame work has been put in place, which includes: National Skills Qualification Framework (NSQF) and Sector Skill Councils (SSCs) for standards (33 SSCs are operational), National Skill Development Agency (NSDA) for administering the NSQF, National Skill Development Corporation (NSDC) for creating/ augmenting the training delivery capacity an exclusive Ministry for Skill Development and Entrepreneurship (MSDE) for coordination. There are many challenges to the quality of the vocational education imparted in India, which has been addressed in this paper, like the Vocational education is not "aspirational" for the students, the parents and the community at large for variety of reasons, social and economic, the current initiative of MHRD in introducing vocational education subjects in schools, although a good beginning seems to be inadequate, both in terms of its reach/coverage and integration with the formal academic system, The schools do not have the requisite workshops, trainers and the industry linkages to impart high quality and relevant vocational skills. It's very important to deal with these challenges, as vocational education will be playing a very important role dealing with the job market and employability in the future. Students and the parent community have to be sensitised about the benefits of skill education and the schools need to be actively taking part in this initiative. Infrastructure needs to be adequate along with the trained manpower to achieve the desired results and quality in vocational education.

KEYWORDS: Education Policy, Vocational Education, Emerging Trends
\end{abstract}

Received: Jun 08, 2020; Accepted: Jun 28, 2020; Published: Sep 17, 2020; Paper Id.: IJMPERDJUN20201315

\section{INTRODUCTION}

"Education is the most powerful weapon with which you can use to change the world- Nelson Mandela"

This article will be dealing at the challenges facing the vocational education stream In India and suggestions to improve the quality of education imparted in the vocational streams.

Vocational Education, Training and Skill Development (VETSD) means all forms and levels of the educational process involving, in addition to general knowledge and academic skills, the study of technologies and related sciences, the acquisition of practical skills, know-how, attitudes and understanding relating to occupations in the various sectors of economic and social life. Vocational Education, Training and Skill Development (VETSD) is further understood to be (a) a means of preparing for occupational fields and for effective participation in the world of work; (b) an aspect of lifelong learning and a preparation for responsible citizenship; (c) an instrument for 
promoting environmentally sound sustainable development; Vocational Education and Training (VET) is an important element of nation's education initiative. For Vocational Education to play its part effectively in the changing global environment, it is imperative to redefine the objectives of vocational education and training and to make it flexible, contemporary, relevant, inclusive and creative. Vocationalisation of education was identified as a priority area in the Eighth Five Year Plan. The revised policy formulations which set forth the modifications to the NPE, however, retained the policy framework laid down by NPE. The target coverage was however, revised to divert 10 percent of the higher secondary students by 1995 and 25 percent by the year 2000.The NPE 2016 Committee recognizes the need for integrating skills with education, particularly in secondary education and outlines the challenges and broad strategy for the future. A comprehensive National Policy for Skill Development and Entrepreneurship was formulated in 2015 and a Mission was set up by Government of India, with the objective of training 40 crore people by 2022. In 83 order to implement the Mission, necessary institutional frame work has been put in place, which includes: National Skills Qualification Framework (NSQF) and Sector Skill Councils (SSCs) for standards (33 SSCs are operational), National Skill Development Agency (NSDA) for administering the NSQF, National Skill Development Corporation (NSDC) for creating/ augmenting the training delivery capacity an exclusive Ministry for Skill Development and Entrepreneurship (MSDE) for coordination. Around 21 Ministries of the Central Government are involved in implementing Skill Development Schemes for their respective target groups. These Ministries and NSDC together have trained around 86 lakh youth during the financial year 2014-15 alone. The State Governments have also been very active in implementing skill development programmes and many of them have established Nodal Institutions for coordination and implementation of programmes. A network of private Training Providers (TPs), incubated, supported and monitored by NSDC, capable of implementing industry relevant short term training programmes with job linkages, has evolved in the country. There are 267 such TPs with more than 4000 training centres, where around 65 lakh persons have been trained till now during the last five years. The industry, public and private sector have also been contributing to skill development programmes by way of participation in SSCs, and financial sponsorship through CSR. 6.9.6 MSDE has taken up a number of measures in strengthening the existing ITIs and creating new ones. It proposes to improve the infrastructure, enhance the quality, and double the existing 18.5 lakh seats by 2022.

\section{CHALLENGES IN VOCATIONAL EDUCATION-}

While noting the several initiatives taken by the Central/State Governments and industry, the Committee observed that there are several challenges in Vocationalization of secondary education. Some of these critical issues include:

Vocational education is not "aspirational" for the students, the parents and the community at large for variety of reasons, social and economic- It's very important to make the parents and the community and the students understand the importance of vocational education and its implications. The various courses which have been introduced are, Retail, Automobiles, Tourism, Mass media studies, Library and information science, Fashion studies, Business studies, Textile design, Beauty Sciences, Horticulture, Food production, Security, Business administration amongst others. These courses have been designed in such a way to impart the professional skills to the students, to gain understanding about the industry in general and imply the knowledge learnt at the school level. Most of the parents and the community at large still value the conventional streams of education like medical, engineering, arts and others which over the period of time have become saturated and it's very important to realise the emergence of a new economy where many new and allied professions have come into emergence, which have a constant deficiency of trained and skilled manpower. It's very important thus to sensitise the students and the community at large about these emerging industries and businesses. This 
could be done in several ways like conducting sessions form the industry professionals who can come and talk about their profession by interesting presentations and case studies. This will create interest amongst the students for the subject and the current scenario for the industry standards and practises. The current initiative of MHRD in introducing vocational education subjects in schools, although a good beginning seems to be inadequate, both in terms of its reach/coverage and integration with the formal academic system. The initiative of introducing vocational education subjects in schools have been received with a very low enthusiasm amongst the schools and the students in general. The students who have opted for these courses are very few and has been run half-heartedly without the adequate infrastructure. This seems to be just being done for the formality at the school levels, so the desired outputs and the over enthusiasm of the students for these courses have been very low. Schools have been running these programs without the desired teachers and professionals who excel in these fields. It's imperative to run these programs from the professionals from the industry with the right amount of experience in the subject matter. These programs should be more practical with field visits to the respective industries to give the students the right amount of exposure and also the inputs on the current trends and happenings in the field, as its expected that the students would be taking the same profession after school or go in for the graduation studies in the same field. The vocational education streams should be designed in such a way that the students get the desired inputs in the respected fields which could give them the right exposure to find jobs and develop the careers. It's very essential to design the program in such a way that it remains updated, easy to understand, induced with the projects from the industry.

The schools do not have the requisite workshops, trainers and the industry linkages to impart high quality and relevant vocational skills. The schools which are imparting these vocational courses should have the right amount of infrastructure and also the skilled manpower with the desired experience of the industry. Different industries would need different infrastructures which would cater to the specialised skill sets. Very few schools have the adequate infrastructure needed to teach these vocational courses. There is a need to evaluate these programmes and the teaching skill sets needed to impart this education. There is also a shortage of trainers to conduct these programmes. Just having the text books with the curriculum is not sufficient to impart the practical and technical aspects of the vocational programmes. Schools should take these programmes very seriously so that the interest levels of the students is sustained and it gets the desired results. Another very important aspect is the lack of industry linkages which are very crucial to the running of these programmes. These could be in the form of visits to the industries, labs, workshops to give the students first-hand experience of the trade they wish to learn. Various internship projects should be devised in the relevant subjects and projects to give students the industry exposure. The industry partnerships can also be very fruitful to look for future placements and the students can also earn some nominal amounts which can be very encouraging. So it's very important for the institutions to have a industry linkage cell to promote these synergies with the industries, to give overall exposure to the students in the relevant fields. While these issues are not conclusive, they provide timely, if not new, eye-openers on what could be considered as necessary foundations for shaping teacher education and refining the role of teachers and learners in the new, independent and engaging environment that has been created for them in the field of vocational education. Some of the suggestions which can be applied are mentioned below.

NVQF: Re-engineering of NCVT as National Vocational qualification and accreditation authority, which can be very crucial.

Socio-Cultural and Socio Economic Diversity: Diverse socio-cultural and socioeconomic background, becomes hindrance in offering a standardized programme. 
Need of Convergence for Skill Development: Strategies and approaches to skill development are different the Gigantic Task-500 million persons in a variety of skills by the year 2022

Involvement of Multiple Agencies/ Departments/ Ministries There are 17 ministries/departments of Govt of India, makes it very complicated. Processes should be simplified for an easy approach.

Standardization of Curriculum and Instructional Resources: A massive effort is required in evolving curriculum and designing instructional resources. This is very crucial

Inadequate Infrastructure: Hardware, building, space, power supply lacking in rural areas.

Shortage of Competent Trainers: Almost for all skill courses there is a serious shortage of competent trainers.

Involvement and Commitment of Private Sector: All students may not get opportunities for acquiring hands on skills

Equivalence of Skill Qualifications: Skill qualifications offered, many a times, are not equated with skill qualifications available abroad.

Social Acceptability of Skill Courses: Social stigma becomes a de motivating factor for youth.

Mind-set of Present Generation: Mind set of present generation is in favour of undergoing training pertaining to white collar jobs Delay in Evolving Sector Skill Councils and National Occupational Standards, Evolving up to date curriculum can't be met in absence of National Occupational Standards.

Design of Curriculum by Experts from Formal Sector: It would made curriculum more relevant if the informal sector is involved in curriculum design.

Absence of Manpower Forecasting: There is no authentic manpower forecasting mechanism in place in India.

Bringing skill development within the domain of universities: The universities should become a significant partners in implementation of Skill Development Mission of the Govt of India.

\section{CONCLUSIONS AND WAY FORWARD}

As a conclusion, the main points of any skills strategy must be detailed and great skills, greater links between the worlds of education and industry. Vocational education is very crucial for the nation's development, and hence all the stakeholders like the schools and the various agencies to take it very seriously. The way forward would be a greater industry and academic synergies and linkages which will form the foundation ground for the skill development sector. It's imperative to realise the importance of vocational education in the country which needs very strong policy backups and funds which are needed to propagate the benefits of skill development. Its very crucial for the youths to understand the importance of vocational education as means of employability and the education imparted should be of greater quality. This is the way forward for the vocational education programmes in India .Industry will play a very crucial role in providing the knowledge and expertise in the related fields. So it's very important to take the industry feedbacks in shaping and reviewing the curriculum. 


\section{REFERENCES}

1. National Education Policy 2016

2. Quality Technical, Vocational Education and Training: A Tool for Self Reliance T.C. Ogbuanya (Ph.D)1 Adameji James Oluwasola2, IOSR Journal of Computer Engineering (IOSR-JCE)

3. NSFQ notification 2013

4. Amakievi Okien Ijeoma Gabriel, "Trends in the Implementation of Nigeria's National Policy on Technical and Vocational Education and Training: 1977-2014 “, International Journal of Humanities and Social Sciences (IJHSS), Vol. 7, Issue 3,pp. 71-88

5. Ajayi, Olusola Olajide \& Ajayi, Olufunke Esther, "E-Learning: A Key to Actualizing Sustainable Educational Development in Africa “, International Journal of Computer Science and Engineering (IJCSE), Vol. 3, Issue 3, pp. 109-116

6. Draft national policy on skill development and entrepreneurship

7. National Skill Development Policy, March 2009

8. Amandeep Kaur, "Effectivness of Instructional Model Based on Mind Brain and Education Science Approach “, BEST: International Journal of Humanities, Arts, Medicine and Sciences (BEST: IJHAMS), Vol. 4, Issue 12, pp. 111-120

9. National Knowledge Commission Report, December 2006

10. Skill Development in India, the Vocational Education and Training System, World Bank Report, 2006

11. Jasbir Kaur \& Babita Arora, "Inclusive Education - An Integrated Approach “, IMPACT: International Journal of Research in Humanities, Arts and Literature (IMPACT: IJRHAL), Vol. 2, Issue 2, pp. 59-64

12. Human Resource and Skill Requirement in the Education and Skill Development Services sector (2022) - A Report by NSDC, India 

